\title{
Study of Hadith Living in All Islamic Boarding Schools in Medan, Indonesia
}

\author{
Ahmad Faisal ${ }^{1}$, Ramli Abdul Wahid ${ }^{2}$, Sulidar $^{2}$ \\ ${ }^{I}$ Ph.D Student in State Islamic Study of North Sumatera (UINSU), Medan, Indonesia \\ ${ }^{2}$ Lecturer in in State Islamic Study of North Sumatera (UINSU), Medan, Indonesia \\ raudatuzahra2010@gmail.com
}

\begin{abstract}
Hadith for Muslims is an important thing because in it revealed various traditions that developed during the time of the Prophet. Traditions that lived during the prophetic period refer to the person of the Prophet. as a messenger of Allah SWT. In it the conditions for various Islamic teachings, therefore, sustainability continues to run and develop until now along with human needs. The continuation of the tradition is so that humanity today can understand, record and implement guidance on Islamic teachings that are in accordance with what the Prophet Muhammad exemplified. Practices of worship carried out are sources of arguments. Therefore, Friday azan twice is a sunnah (habit) which was revived during the leadership of Caliph Usman bin Affan. Because at the time of the Prophet Muhammad. the usual Friday call to prayer is only one time. The reason why Usman did this was because of the progress of the Islamic region and the increasingly busy activities of Muslims. So to perform Friday prayers is not enough to call only once.
\end{abstract}

Keywords : Al Quran; hadith; Islamic boarding school; sunnah

\section{Introduction}

Hadith for Muslims is an important thing because in it revealed various traditions that developed during the time of the Prophet. Traditions that lived during the prophetic period refer to the person of the Prophet. as a messenger of Allah SWT. In it the conditions for various Islamic teachings, therefore, sustainability continues to run and develop until now along with human needs. The continuation of the tradition is so that humanity today can understand, record and implement guidance on Islamic teachings that are in accordance with what the Prophet Muhammad exemplified.

If it refers to the tradition of Prophet, which is now by the scholars of hadith has been used as a verbalized so as to bring up the term hadith and to distinguish it from the term sunnah, then in it the conditions for an established order in the life of the community, state and religion. The figure of the Prophet Muhammad which was made a central figure and followed by the community afterwards. Until here, the term popular among the people is the term hadith.

So, it is natural that Muslims then compete in practicing what has been practiced and carried out by Muhammad. that is. Because only by practicing it directly, hadith still feels alive in the community until now. They are in droves trying to make every thing they do in their daily lives have a clear backing, the hadith of the Prophet. This phenomenon of community behavior based on the hadith is called the living hadith.

Living hadith is a reception (reception, reaction, response or response) of a Muslim community group that comes from a Hadith. The situation is both in the form of personal (personal) and that which occurs in the life of the community. Living hadith is a form or form 
of mixing two or more cultures that meet and influence each other between the doctrines of Islamic teachings and some local cultures. This action then produced a tradition known as living tradition or if it was based on the Hadith, called the living hadith.

The definition of living hadith also examines hadith as living texts, while the living hadith approach emphasizes the aspect of hadith which is interpreted as everything that is attributed to the Prophet Muhammad. In this case it can be said that someone who is proficient in mastering the doctrinal methods and application of living hadith or who wants to study and examine hadith in the context of the theory of living hadith means that he is expected and expected to become a hadith scribe (syārihu al-hadīis). The purpose of the definition of syāriḥu al-ḥadīis here is one who explains various hadiths and meanings contained in them, and is not limited to mere commentary and explanation, but also includes various methods related to various other sciences in the science of hadith and figh, such as takhrij al-hadisis $\dot{s}^{1}$, the study of the isnād of hadith, the grammatical analysis of various lafaz hadiths, explanations of several words which are garib, an explanation of the various mythical and abstruse traditions, nāsikh and mansükh hadis and the causes of their wurüd, and fiqh al-hadìs benefits contained in it.

Throughout the living hadith discussion, is there discussed the guiding requirements of hadith (syārihu al-hadīis), while the study of living hadith aims to make smart people share hadith with the living hadith method. Because living hadith is a reception (reception, reaction, response or response) of a Muslim community group that comes from a Hadith. The situation is both in the form of personal and that which occurs in the life of the community. A person who wants to do the living Hadith research must have the characteristics and conditions of the hadith and his customs.

As for the author, the characteristics of the criteria for the guidance of hadith as well as its customs are several cases and problems that must be fulfilled so that a living Hadith researcher can be involved in the field of hadith narrative, understanding of hadith meanings and conclusions from instructions as-sunnah an-nabawiyyah.

So far, based on journals, articles and reading books, I have never talked about this. Therefore it is necessary to talk about the conditions of the people who study living hadith, because it is very irrational that someone who does not understand Arabic becomes syārihu al-hadìis, or becomes an exegete for the Al-Qur'an.

\section{Review of Literature}

\subsection{Characteristics of Pensyarah (Lecturer) of Hadith}

A lecturer should have some characteristic characteristics, so he can be called experts and experts in the field of hadith. Some of these attributes or characteristics are as follows;

\section{a. Have a sincere intention}

Intention is the initial foundation before doing the job. All actions arising from a believer are considered true when accompanied by intentions. Therefore, the first hadith lecturer must be sincere and intentionally correct. In one of his hadith, Rasulullah saw. said:

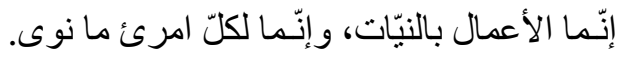

\footnotetext{
${ }^{1}$ Explanation of various methods as well as valid assessments or weaknesses. DOI : https://doi.org/10.33258/birci.v2i2.252 
"Every action depends on intention, and each person depends on the intention he has."

The purpose of the word an-niyyatt is something that is intended as a goal or niyyah is a destination that one leads to the place. Imam Nawawi defines the intention with al-qasdu wa'azimatu al-qalb, meaning the purpose or willingness of the heart. But a lecturer should emphasize his desired purpose by directing his actions to the Prophet's service, as well as the dissemination and presentation of the meaning and the hadith as a form of practice from the Messenger of Allah:

"Tell it even only one sentence."

بلّغوا عنّي ولو آية

Therefore, pensyarah (lecturer) must truly devote his heart and do this act solely because Allah Almighty, seeks His pleasure and expects His reward not to elevate his position in the human eye, not to make this act as one of the worldly professions such as being a mufti, teacher, judge, to debate ulama, to gain glory or various other reasons that deny the direction of practice solely because Allah Almighty.

\section{b. Seriousness in Demanding Knowledge}

Demanding knowledge is the most noble deed done by man throughout his life. Because of this, God commands humans to always ask for the addition of knowledge, as He says,

\section{"And say: O my Lord, add to me knowledge." ${ }^{2}$ Q.S. Țāha / 16: 114}

$$
\text { وَقَقْ رَبِّ زِدْنِي عِلْمًا }
$$

This is quite an explanation for the very noble position of science. Demanding knowledge is very important, because it is also part of following in the footsteps of salaf people. This is what becomes the goal of scribes by combining several histories and opinions. This amalgamation will broaden the knowledge of the narrators of the hadith and make it much known to the opinions of the salaf and khalaf scholars and better in presenting the theme and explanation of Hadīs asy-Syarîf and discussing related opinions.

\section{c. Patience and Courage}

Conducting scientific writing, finding solutions and education is an act that requires time and at the same time patience. Allah SWT. say in the Qur'an,

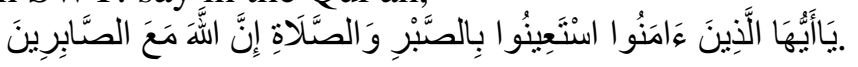

"O ye who are believer, make patience and pray as your helper, in fact Allah Almighty. along with those who are patient "QS Țāha: 153

Usually a director begins his activities with a strong desire, but also can quickly give up and fade his desires and lose patience when facing various obstacles, such as difficulty finding adequate sources, finding difficulties when takhrij hadith, giving an assessment of a hadith, placing and compile it in a desired specific title, referring to the explanation of comparative opinions and various other matters related to the discussion of the hadith tradition. A scribe must be patient because his actions are part of worship. Patience in undergoing worship is a compulsory act, even part of faith.

\footnotetext{
${ }^{2}$ Departement of Religion of RI., Al-Qur'an and its tranlation (Riyadh: Darussalam, 2006), p. 444. DOI : https://doi.org/10.33258/birci.v2i2.252 


\section{d. Bravery}

The meaning of courage here is not in dealing with a variety of dangerous conditions, but the courage to think that is courage in being responsible in giving birth to thoughts, accuracy in truth, informing what is obtained correctly and clearly even though his opinion is contrary to a habit, school or a group, not tilted by wind, only to get the pleasure of the leader, a group or friend.

\section{e. Adab (Culture)}

Adab to the Messenger of Allah. is one of the things that every Muslim needs at every time and place. Allah SWT. say,

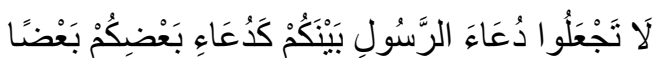

"Do not make the call of the Apostle among you as part of your call to others (others)."3 Q.S. an-Nūr / 18: 63

Allah SWT. say,

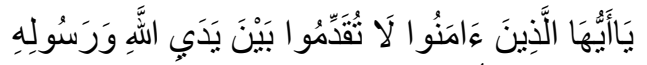

"O ye who believe, do not overtake Allah and His Messenger and fear Allah." ${ }^{4}$ Q.S. alHujurāt / 26: 1

Adab, fadilat, charity and morality are some of the pillars in interacting with as-sunnah an-nabawiyyah, and the Prophet. considered a Shari'a delivery teacher who delivered it from Allah. Therefore we should not be grateful for his words except those that are in accordance with what the Salaf have done, in accordance with the Shari'a and sound reason.

\section{f. Al-Maudū'iyyah (Objectivity)}

The notion of al-Maudū iyyah is neutrality and impartiality when expressing opinions and discussing various themes of discussion. A good researcher is a researcher who sees a nature with an objective view that is only a matter of personal, or related to a school, group or country. Shaykh Jamāl ad-Dīn al-Qāsimī quoted an article by one of the scholars, which in my opinion illustrates their situation which excludes the side of objectivity. He said, "You can see that there are some people who, if they get a hadith that is in accordance with their school / sect, will be happy and accept it. Whereas if you get a legitimate hadith which is separated from the narration and the refutation that strengthens the school other than the imam of the school, then he will include it in the ihtimâlät (tendency / possibility) which is far away and does not give adequate attention while looking for various sides of tarjīh in the opinion of the imam. best friends, tabiin and nas ass-ṣarih. When writing a book of hadith narrations, he will exclude everything that is contrary to him. But if it can't be like that, then he will claim the hadith has been deleted (naskh) without any evidence that proves it and other actions that show his mind is sick. They defended the imam of their school excessively, contained various positions and their speeches in various chapters and believed that all who contradicted the imam of his school were not right."

\footnotetext{
${ }^{3}$ Departement of Religion of RI., Al-Qur'an and its tranlation (Riyadh: Darussalam, 2006), p. 501.

${ }^{4}$ Ibid., p. 743.

DOI : https://doi.org/10.33258/birci.v2i2.252 


\subsection{Adjudicating Hadiths}

Ethical etiquette means mā yata'addabu bihi al-'adīb min an-nās, that is something done by a civilized person from among humans. Named adab because he is the one who educates and directs to commendable behavior and prevents him from being despicable. Adab also means self-training with proper teaching and self-correction. Adab means meaning good treatment. Adab can also be interpreted modesty, subtlety and kindness. The result of adab is repairing someone who preoccupies himself with the tradition of hadith and applies the adab. Among others are:

\section{a. Asking for help to Allah SWT}

Allah SWT. has taught us to ask Him for help, even obliging us to always repeat it. Allah SWT. say in the Qur'an,

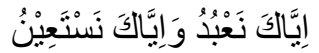

"You are the only one we worship, and only to You we ask for help." QS. al-Fatitiah / 1: 5

\section{b. Seriously in Doing Sharah}

For a counselor, it is obligatory to fulfill all the rights of syarah and not just to do the sharah. But he must issue various seriousness according to his ability to apply the method he wants to follow in carrying out the activities of the hadith tradition. ${ }^{5}$ Sharar actors refer to the various methods he wants to hold in his book and apply them at the beginning of his book. Therefore, something that is demanded from a director is ihsan in his work. The Koran has given good news to people who are muhsin in their deeds to get merit.

Allah says,

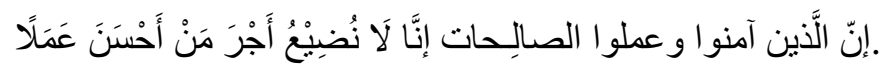

"Surely those who believe and do good works, surely we will not waste the reward of those who do good deeds" QS. al-Kahf / 15:30

Rasulullah saw. has encouraged Muslims to do a perfect deed (itqān). He said,

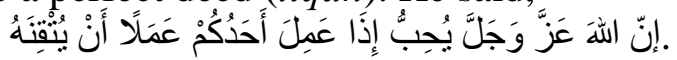

"God likes if one of you does a charity in a way."

\section{c. Not Commenting When Doing Sharah and Explaining Its Meanings Without Knowledge}

Sharah actors may not engage in the activities of hadith prayer and explanation of various meanings without any knowledge possessed. In fact, he must refer to various expert opinions and ask them. Allah says in the Qur'an,

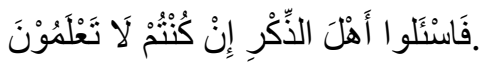

"Then ask someone who has knowledge if you do not know." Q.S. an-Nạ̣l / 14: 43

It is said that when a child Abdullāh ibn 'Umar was asked about something he did not know. Then Yahya ibn Sa'īd said, "By Allah I will not want to be like you even though you are the son of my priest (Umar and Ibn Umar) whom you are asked something you do

${ }^{5}$ Al-'Asyrafī, asy-Syarh al-Maud̄̄ 'ì, p. 109. 
not know. Then he said, "By Allah, I will not say something I do not know or tell something that cannot be trusted."6

Imam Ahmad was once asked about the interpretation of one of the gharīb words in the hadith, then he was silent and then he said, "Ask the experts (the words) gharīb, actually I do not like to talk about the words of the Prophet with guesses, then I am wrong." When Syu'bah was asked about one of the lafaz traditions, he said, "Try asking al-'Așma' $\overline{1}$, because he knows more about this than us."

Such is the sincerity of the salaf aș-sālih, they are all very careful and restrictive to the words that come from the Hadith of the Prophet. without knowledge.

\section{d. Didn't Ensure What are found by Sharah Really Mean The Prophet.}

One $a d a b$ that must be applied by a director is to investigate the meaning of the lafazlafaz hadith, especially those who have various tendencies and do not ensure that what he found in the shrine is really the intention of the Prophet. doing hadith is not an easy matter. For hadith experts, ignorance of the hadith tradition is a despicable act, it will be difficult for those who want to know it, it is worth investigating by recording and explaining the traditions of the hadith.

\section{e. Trying to Release Islam from Various Allegations}

Sometimes a philanthropist when conducting a collection, the gift of the hadith faces various accusations. In conditions like this, he must defend and defend the various allegations (against the teachings) as he can, as the Salaf priests have done such as Ibn Qutaibah al-Dinawarī in his book "Ta'wīl Mukhtalif al-Hadīis" and others. ${ }^{7}$

\section{f. Maintaining Scientific Trust}

One of the most important falsehoods that must be had by a hadith scribe is to have a scientific mandate.

\subsection{Activities and Limitations of the Living Hadith Research}

Islamic scholars have recently begun to develop what is called the hadith living. The study of living hadith focuses on the understanding and practice of hadith in the lives of everyday Muslim societies. A person's understanding of the text of the hadith of the Prophet is not the same, this depends on the educational background, interests, socio-political context and culture of the people who understand it. Likewise practice in society. The same hadith text can be practiced differently by the Muslim community. This happens because of the acculturation (mixing two or more cultures that meet and influence each other) Islam with the local culture.

Because living hadith is a reception (reception, reaction, response or response) of a Muslim community group that comes from a Hadith. The situation is both in the form of personal (personal) and that which occurs in the life of the community. This means that all findings that are practiced and believed to originate from the hadith of the Prophet are legitimate as a theoretical concept of the living hadith.

\footnotetext{
${ }^{6}$ Abī Zakariyya Yahyya ibn Syaraf an-Nawawī, al-Minhāj Syarh Șahịh Muslim ibn al-Hajjāj (Dimasyq: Dār alFaihāà, 2010), Juz I, h. 151.

${ }^{7}$ Al-'Asyrafì, asy-Syarh al-Maudū 'ī, h. 112.

DOI : https://doi.org/10.33258/birci.v2i2.252 
The theory of living hadith is now open, because there are no boundaries, there are no conditions for the exegete or syārih al-ḥadīṣ. Every interpretation by anyone is seen as legitimate. Interpreters in this case are free of anyone without interpreter's conditions and without signs, covering all verses and Hadith, including verses and hadith about faith and worship. This view, free of values and unlimited contextual will exceed the value of faith.

In fact, at this time the development of theories about living hadith can be said to have exceeded limits, such as attitudes to adopt Western thought whose concepts are without the interpreter's conditions, without signs and without boundaries and abandon the theories of the study of Hadiths that have been built by scholars since centuries -centuries ago. As for the author, I mean that insofar as the existing theories are about the discussion of the hadith living, are there any limitations on which living Hadiths are allowed and which are not Hadith living ?, Are there no segregations and restrictions, for example the traditions of the faith are not Living Hadith can be said, which means that all what is found about the traditions of faith, worship, muamalah, law, morality, values and so on, there must be scope and boundaries that are not affected by dimensions space and time. So far, based on journals, articles and reading books, I have never talked about this.

In the meantime, to find out which boundaries are allowed by living hadith and which ones not living hadith should have hadith observers and living Hadith researchers must know two things about the science of space (spatial) and time (temporal) in the study of sciences Hadith or can be called 'ilmu al-Bu'dain az-Zamānì wa al-Makānī fì al-Hadìs.

What is meant by the dimension of time (al-bu'duaz-zamānī) in the hadith is the condition of those who interact with the Prophet during the prophetic period of 23 years. Whereas what is meant by the spatial or spatial dimension (al-bu'du az-zamani) is the state of the Arab region in terms of environment, climate, customs, traditions, activities and concerns experienced and felt by the Prophet during the 23 years of prophethood.

The essence, the dimensions of time and space are related to one another and not separate. Because the human condition felt by the Prophet during the prophethood was the Arabs who were inhabitants of the Arabian Peninsula, so that both dimensions were experienced by the Prophet and he also interacted with him for 23 years. ${ }^{8}$

This is a new science in the study of hadith, although it has a relationship with the cause of the decline of a hadith (sabab al-wurüd al-hadīis), but in the form of dimensions of time and space. We include this knowledge in the study of hadith for the first time in its history with the aim of discussing the hadith from its influence in the understanding of the Sunnah and as one method of explanation of the hadith texts and applying them to various realities and capacities as one of the teaching aids in understanding the hadith texts on this time.

Based on a number of Hadiths and asar collected to discuss the limits on which living Hadiths are permissible and which ones are not living Hadiths, as well as the influence of Hadiths and Ahar in the dimensions of time and space, the authors find the following conclusions:

a. The scope and boundaries that are not living hadith (sunna which are of eternal nature) because they have no effect on both dimensions (aś-sंawābit):

- The scope of static faith. The law does not change unless forced.

\footnotetext{
${ }^{8}$ Ibid.
} 
- The main points of worship are Taharah's obligation, prayer, fasting of Hajj and Zakat. Then the law does not change and the number and method of implementation, except those related to the way it is implemented when in a state of aging.

- General principles of Islam in terms of muamalah, law, justice and others. Like the basis for deliberation. The basics are halted by buying and selling, syirkah, leasing, loans, justice and equal rights. The basics are forbidden to eat property in a vanity way such as usury, risywah, stealing, robbery and wrongdoing. The basics of the marriage, talak, khulu ', iddah (menstrual period) are halted. Likewise, the basics are forbidden from relating to the opposite sex which is not recited as adultery, liwat, sihaq (lesbi). Legal and qișāṣ basics, and so on.

- Morals and values. Such as honest beauty, trustworthiness, faith, courage, courtesy, and others from commendable morals. Also like lying badness, betrayal, dana $\bar{a}^{\prime} a h$ (dirty), cowardly, stingy and others from despicable morals. These all do not change the beauty and ugliness of those who are affected by time and space, except in circumstances that are allowed to lie for benefit.

- Divine Sunna. Allah says in the Qur'an,

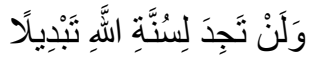

"And you will never find a change in the sunnah of Allah."9 Q.S. al-Aḥzāb / 22: 62, Q.S. al-Fath / 26: 23

The sun rises to the east and sinks to the west, the creation of humans and animals from the meeting of sperm and ovum, falling rain, changing seasons from winter and summer, spring and autumn and other sunnatullah have no effect in terms of dimensions of time and space. It never changes and changes will not be found in it except with the permission, will and power of God.

- Various problems that are specific to the Prophet such as the obligation of the evening prayer, the obligation to pray duha, the necessity of wișāl fasting, and not marrying off the female child while living with other women and others.

These things do not affect these two dimensions, and this shows that these problems belong to the unchanging tsawābit category. There is no influence of these two dimensions on the situation except in certain circumstances (emergencies). Because the provisions of the cases are a form of safeguarding the Islamic community from damage and collapse as well as part of the practice of the sustainability of the Shari'a and its development based on a variety of solid machine support that cannot be broken by lust and changes in society. This Tsawabit affirms the Islamic Shariah as something clean and cleansing in all places and times, in various environments and communities, and in every country, city and village. ${ }^{10}$

\section{b. The scope and limitations of the living Hadith (sunnah that follows the situation) or areas that can affect both dimensions (mutaghayyirät)}

- Related to the hadith related to the basic branching of worship or the application of previous basics.

- Related to the command of the prophet addressed to the rulers of the country and the leader of the army, delegation selection, troop administration, the design of war

\footnotetext{
${ }^{9}$ Departement of Religion of RI., Al-Qur'an and its tranlation (Riyadh: Darussalam, 2006), p. 603.

${ }^{10}$ Ābādī, 'Ulüm al-Hadìsं, p. 412. 
strategies, the spread of boundaries of settlements and cities, the separation of property in various benefits, agreement conclusions, restrictions on $t a$ ' $z \bar{z} r$ sentences and their implementation, methods of hudud punishment and $t a ' z \bar{z} r$, restrictions on time and boundary conditions and others.

- Relating to human experiment methods, customs and habits. Like some of those found in medical traditions and other worldly matters.

- the deeds of the Prophet's custom, commands for encouragement such as eating, drinking, walking, sleeping, movement and others

These things include mutaghayyirāt (which changes) that promotes the flexibility of Islamic law, where this case is given the opportunity of the jurisprudence ijtihad to get legal conclusions in accordance with human conditions, traditions and customs along with safeguarding various general rules of sharia that deny difficulties, and build laws based on convenience and spaciousness. Shari'a has obliged this part of protecting the masses of people and their needs.

Different laws (over time and changes in circumstances and habits) in realizing this benefit are not considered appropriate to be applied in a variety of new circumstances and regions. Because the law as we know it always revolves around the illat whether it exists or not. Therefore, many of the muta'akhirin fiqh clerics from various schools gave birth to different fatwas from the fatwas of the priests of the school. This muta'akhirin cleric explained that the reason for the difference in their fatwas was due to differences in time and time, not related to differences in argument or proof.

The author also observes from several hadith and asar that the two dimensions cover the following conditions; 1. Habit, 2. Adat, 3. Social situation, 4. Economy, 5. Culture, 6. Benefit, 7. Purpose, 8. Politics, 9. War situation, 10. Safe situation, 11. Political law, 12. Room / Place, 13. Time, 14. Health and others. However, the author does not mention a few examples of these traditions for fear of extending the writing, but the author tries to cover them in some examples of standard sizes that can be influenced by the two dimensions on the next page.

\section{Discussion}

The tradition of living hadith is indeed often found in Muslim communities in Indonesia, especially those in pesantren. Islamic boarding schools or better known as Islamic boarding schools are the oldest Islamic educational institutions that are products of Indonesian culture. In the history of national education, pesantren are community-based educational institutions. Islamic boarding schools have fused and developed from the community, then developed by the community. Islamic Boarding Schools are Islamic educational institutions in Indonesia, where kiai and santri live together in a community that has five basic elements, namely huts or dormitories, mosques, classical Islamic books, santri and kiai or teacher educators. The portraits of santri activities and daily worship practices in pesantren are usually coordinated by cottage caregivers.

There is a shift in views about the traditions of the Prophet Muhammad. which led to the standardization and making of hadith as a narrowing of the scope of the sunnah, causing the study of living hadith to be interesting to be studied seriously and deeply. The fact that develops in the community implies the existence of various forms and kinds of interactions between the Islamic ummah and the teachings of the second Islam after the Qur'an. The 
reason is none other than the change in the knowledge and technology that is accessed. In addition, knowledge continues to develop through education and the role of preachers in understanding and spreading the teachings of Islam. It is precisely here, society is the object of study from the hadith living. Because in it the interactions between hadith as Islamic teachings with society are varied in various forms.

From the description above, it can be said that the hadith of the Prophet Muhammad. the reference to the Islamic ummah has been manifested in the life of the wider community, especially in the pesantren community. Compatibility of written, oral traditions and practice traditions with the hadith of the Prophet. it seems feasible to be studied in this study, because the santri and the pesantren community have not realized much that the traditions they did were not all true from the Prophet. Very many examples of the use of the hadith of the Prophet. which is related to living hadith that has been applied in the community of Islamic boarding schools.

In the meantime, the focus of the study of living hadith is a study of the fact of the phenomenon of practice, tradition, ritual, living behavior in the community that has a connection with the hadith of the Prophet. There are at least three variations and forms of hadith living in this study. These three forms are written traditions, oral traditions, and traditions of practice. The three forms will be examined in this scientific research as follows:

\subsection{Written Tradition}

The writing tradition is very important in the development of hadith living. Writing writing is not only limited as a form of expression that is often emblazoned in strategic places such as buses, mosques, schools, boarding schools, and other public facilities. There is also a strong tradition in Indonesian treasures originating from the hadith of the Prophet Muhammad. as displayed in various places.

Not everything that appears comes from the hadith of the Prophet Muhammad. or of which there are those that are not hadith but in the community it is considered a hadith. Such cleanliness is part of the faith (النظافة من الإيمان) which aims to create an atmosphere of comfort and cleanliness of the environment, loving the country as part of the faith (حب الوطن من الإيمان) which aims to arouse nationalism and so on.

Another example is the hadith about eating and drinking, the sentence is displayed in the place of drinking water, namely the hadith يشربن أحدكم قائما. The text of this hadith is incomplete, but if we trace back to the main book the hadith of the hadith text are:

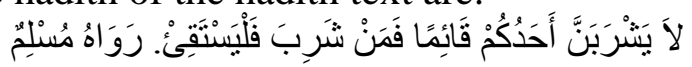

This hadith contains a very subtle prohibition on drinking behavior while standing. The explanation of the prohibition in the hadith shows that it is forbidden to drink while standing without age. But there are also many other traditions that show that the Prophet also drank while standing. The traditions which describe drinking while standing are possible because they are old like a narrow place, or crowded and crowded, or also because the place of water depends.

Furthermore, there are also recitations of prayers which are displayed in the santri classes of Islamic boarding schools. Like the prayer before learning that is clearly written on the wall of the classroom, the reading is:

$$
\text { اللهم افتح لنا أبو اب حكمتلك وانشر علينا من رحتلك وامنن علينا بالحفظ و الفهم ، سبحانك لا علم لنا الا ما علمتنا إنك أنت }
$$

While the after-study prayer is written as follows:

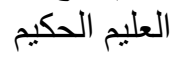




$$
\begin{aligned}
& \text { اللهم إنا نستودعك ما تعلمناه وفهمناه وحفظناه فرده إلينا ساعت اليه و لا تتسناه و افتح علينا يا نور السموات و الأرض } \\
& \text { و الحمد لله رب العالمين. }
\end{aligned}
$$

There are also prayers written on each exam question sheet. Like the prayer below:

$$
\begin{aligned}
& \text { اللهم لا سهل الا ما جعلته سهلا و أنت تجعل الحزن إذا شئت سهلا. } \\
& \text { اللهم وفقنا في جميع الامتحانات واجعلنا من الصابرين. }
\end{aligned}
$$

The above prayer is not written from the Qur'an or Hadith. Sometimes, in asking for kindness to Him, or begging to be avoided from the ugliness of the community the boarding school prioritizes the use of prayers obtained from spiritual teachers, then overrides prayers sourced from the Qur'an and the Hadith of the Prophet. We should as Muslims use various prayers scattered in the Qur'an and the Hadith of the Prophet. because the various prayers listed in the two sources are revelations revealed only to the Prophet and the Apostle.

\subsection{Oral Tradition}

Oral traditions in the hadith living actually appear along with actions carried out by Muslims. Like the recitation of salawat in the pesantren community which is sung and accompanied by music, wooden punches, tambourines or the like. The term salawat comes from Arabic "āalāt" plural nyaalawāt, whose basic meaning is prayer or prayer. Reading salawat in the religious understanding of Islam is praying for the Prophet Muhammad. to get additional grace from Allah Almighty. and direct orders from God Himself to those who believe. Allah says in surat al-Aḥzāb verse 56:

$$
\text { إن اله وملآئكته يصلون على النبي يأيها الذين أمنو ا صلو عليه وسلمو ا تسليما. }
$$

In practicing these religious orders, many ways are carried out with various purposes and purposes, whether religious or community (such as fostering the tradition of friendship, fostering a spirit of social unity) and such traditions have indeed flourished in the Indonesian culture, since Islam has not developed, so that the tradition of salawätan which is done in groups (jama 'ah), using interesting songs coupled with treats or drinks is modest, is a form of inculturation (the effort of a religion to adjust one's appearance to local culture) in order his da'wah.

\subsection{Practice Traditions}

Tadisi practice in living hadith tends to be mostly carried out by Muslims, especially in the pesantren community. This is based on the figure of the Prophet Muhammad. in conveying Islamic teachings. One of the problems is the problem of prayer.

Like the phenomenon of the practice of prayer in congregation at the Islamic Boarding School of ar-Raudlatul Hasanah at the beginning of the new year of the hijriyah. Prayer has become a tradition practiced. Prayer and prayer are carried out with 11 rak'ahs and the reading of the letter after al-Fatiha is short letters, starting from surah al- 'așr to surah an-nas. There are also a number of phenomena regarding the Friday call to prayer, recitation of the letter after the alfatihah, as well as the sunnah qabliyah and ba'diyyah prayers on Friday. There are also sunnah qabliyyah maghrib prayers. 


\section{IV.Conclusion}

Based on the description of the results of the research conducted, the application of the Prophet's hadith in the boarding school institutions in Medan, was found:

\subsection{Writing Phenomenon}

In the writing phenomenon of this paper it is found that the written tradition of writing hadith has been carried out in Islamic boarding schools which are displayed in several strategic places, such as in classrooms, dormitories, kitchens and several other public facilities.

a. Prayer Before and After Dawn.

The writing of this hadith is an invitation to always rely on Allah in educational activities. This is considered important because there are traditions which state the primacy of prayer before dawn, and the existence of traditions that emphasize worship after dawn until the sun rises.

b. Writing prohibition on drinking by standing

This hadith is found in the kitchen and several drinking facilities provided in the pesantren. The author found several histories in this hadith such as the history of Muslims, Ahmad, Tirmidhi, Abu Daud and Ibn Majah.

c. Written in the mosque

This article is contained in the mosque, which is related to the implementation of worship such as prayer. Among them is about the position of prayer for a Muslim, which distinguishes it from unbelievers. The author found several histories of this hadith, namely Muslims, Abu Daud, Ahmad, Ibn Majah and Ad-Darimi and others.

d. The basic hadith of Islamic teachings (read: pillars of Islam. This hadith is found in the Al-Kautsar Islamic Boarding School. Some histories of this hadith are found such as in Shahih Bukhari, Shahih Muslim, Sunan Tirmidzi, Nasa'i, and Musnad Imam Ahmad and others

e. Hadiths that are regulated by sharia business contracts, namely Murabahah. Where this hadith is found in the verses of the Qur'an in Eid murabahah financing contract in the Islamic Boarding School Cooperative. This includes the tradition of living the Koran. In addition, hadiths that were of good quality and hasan were found, which if traced among them were four different lines of sanad.

\subsection{Oral Phenomenon}

a. Read Shalawat when Bel Rest

Based on a number of hadith found in various books of hadith, the author finds that lafaz recitation of the most concise prayer according to the argument is Allahumma Shalli Wa Sallim 'Ala Nabiyina Muhammad. regarding the hadith regarding recitation, the author found eight historical narrations with a valid predicate with different hadith editors

b. Read Prayer Before Learning. This reading is a letter of Al-Fatihah, where it is in accordance with the hadith of the prophet related to reading Al-Fatihah before doing good deeds, including learning. The author sees the phenomenon that has become a tradition in Islamic Boarding Schools, namely reading Surah Al-Fatiah before starting 
teaching and learning activities and before the exam takes place. This is in accordance with several traditions which signal the primacy of Surah Al-Fatihah

\subsection{Practice Phenomena}

a. Total Moon Eclipse Prayers

The practice of prayer was carried out at the time of the Total Moon Eclipse in Medan City some time ago.

b. Hadith Regarding Sunnah Prayer qabliyah maghrib

Hadiths regarding the sunnah qabliyah evening prayer are also found inside the pesantren. Moreover, indeed in the pesantren the sunnah prayer is still encouraged.

c. Pray Tahajud 11 Rakaat in the 1st Muharram Event. Where reading after surah AlFatihah is short letters from Surah Al-Ashr

d. Cupping Tradition

Cupping, which is a method of cupping treatment, is also widely applied in the world of boarding schools. Many traditions related to this tradition are also found in Islamic boarding schools.

e. Implementation of Syari'iyah Ruqyah

Ruqyah syar'iyah is also widely practiced in the world of boarding schools, considering that there are also many disorders that cause trance. Therefore the traditions about ruqyah recitations are also found in the pesantren.

\section{References}

Alfatih Suryadilaga, Aplikasi Penelitian Hadis dari Teks ke Konteks. Yogyakarta: Teras, 2009.

Haifā' 'Abd al-'Azīz al-'Asyrafī, asy-Syarḥ al-Mauḍ̄ 'ci li al-Hadī̇ asy-Syarīf. Al-Qāhirah: Dār as-Salām, 2012.

Muḥammad ibn Ismā‘̄il ibn Ibrāhīm ibn al-Mughirah al-Bukhārī, al-Jāmi 'u aṣ-Sahīh alMusnad min Hadīis Rasūlillāh wa Sunanihi wa Ayyāmihi, Kitāb Bad'i al-Wahy, Bāb Kaifa Kāna Bad'u al-Wahy ila Rasulillāh. Ar-Riyāḍ: Maktabah ar-Rusyd, 2006.

Muslim ibn al-Hujjāj an-Naisabūrī, Șah̄ịh Muslim, Kitāb al-Imārah, Bāb Qaulu: Innama alA'māl bi an-Niyyāt. As-Su'ūdiyyah: Dār al-Mughn̄i, 1998.

Ibn Manẓūr, Lisān al-'Arab. Al-Qāhirah: Dār al-Hadīì, 2003.

'Abd ar-Ra'ūf al-Munāwī, Faị̂ al-Qad̄̄r Syarḥ al-Jāmi 'u aṣ-Ṣaghīr. Beirūt: Dār alMa'rifah, 1972.

Abū aț-Țayyib Șiddīq ibn Hasan al-Qinnaujī, Abjad al- 'Ulūm al-Wasȳ̄ al-Marqūm fì Bayāni Aḥwāl al-'Ulūm, taḥqīq: 'Abd al-Jabbār Zakār. Beirūt: Dār al-Kutub al-'Ilmiyyah, 1978.

Departement of Religion RI., Al-Qur'an dan Terjemahnya. Riyadh: Darussalam, 2006.

Aḥmad ibn 'Al̄̄ Abū Bakr al-Khațīb al-Baghdādī, al-Kifāyah fì 'Ilmi ar- Abū Ya'la Aḥmad ibn 'Alī ibn al-Muṡanna al-Maușilī, Musnad Abī Ya 'la al-Maușilī. As-Su'ūdiyyah: Dār al-Qiblah li aś-Śaqāfah al-Islāmiyyah, 1988.

Abī Zakariyya Yạ̣ya ibn Syaraf an-Nawawī, al-Minhāj Syarh Ṣahīh Muslim ibn al-Hajjājj. Dimasyq: Dār al-Faiḥā', 2010. 
Muḥammad ibn 'Abd ar-Raḥmān as-Sakhāwī asy-Syāfi‘̄i, Fatḥ al-Mughīs bi Syarh Alfiyati al-Hadìis. Ar-Riyāḍ: Maktabah Dār al-Minhāj, 2005.

Abd ar-Raḥmān ibn Abī Bakr jalāl ad-Dīn as-Suyūṭī, Tadrīb ar-Rāwī fì Syarh Taqrīb anNawawī. Mamlakatu al-'Arabiyah as-Su'ūdiyyah: Dār al-'Āṣimah, 2003.

Abī Zakariyya Yạ̣ya ibn Syaraf an-Nawawī, al-Minhāj Syarh Ṣah̄ịh Muslim ibn al-Hajjājj. Dimasyq: Dār al-Faiḥ̄̄', 2010.

Muḥammad Khalaf Salamah, Lisān al-Muhaddisīn. Saudi Arabia: al-Maktabah asySyamilah, 2007.

Fatḥ ad-Dīn bayānūn̄i, "Aḍ̂ā' 'ala 'Ilmi Syarḥ al-Ḥadīs” dalam ad-Dirāsāt al-Islāmiyyah Faṣliyyah Muḥakkimah tabḥaśu fī ad-Dīn wa aś-Śaqāfah wa at-Tārīkh wa al-Ādāb. Oktober-December, 2007.

Abī al-Qāsim Sulaimān ibn Aḥmad aṭ-Ṭabrān̄̄, al-Mu jam al-Kabīr. Al-Qāhirah: Maktabah ibn Taimiyyah, t.t..

Aḥmad ibn Ḥanbal, al-Musnad. Al-Qāhirah: Dār al-Ḥadīs, 1995.

Muhammad Abū al-Lais al-Khair Ābādī, 'Ulūm al-Hadīs Aṣīluhā wa Mu'așiruhā. Kualalumpur: Maktabah Qourtuba, 2018.

Zain ad-Dīn ibn Ibrāhīm al-Ma'rūf bi ibn Nujaim, al-Asybāh wa an-Nażā'ir. Dimasyq: Dār al-Fikr, 1983.

Abī 'Abdillāh al-Ḥākim an-naisabūrī, al-Mustadrak 'Ala aṣ-Ṣaḥịhain. Beirūt: Dāar alMa'rifah, t.t.

Aḥmad ibn al-Ḥusain ibn 'Alī al-Baihaqī, as-Sunan al-Kubrā. Beirūt: Dār al-Kutub al'Ilmiyyah, 2003.

Abī Ja'far Muḥammad ibn Jarīr aț-Ṭabarī, Jāmi 'u al-Bayān 'an Ta'wīl Āy al-Qur'ān, taḥqīq 'Abd al-Muḥsin at-Turkī. Gīzah: Dār Hajar, 2001.

Abū Dāwud Sulaimān ibn al-Asy'aś as-Sijistānī, Sunan Ab̄̄ Dāwud. Ar-Riyāẹ: Baitu al'Afkār ad-Dauliyyah, t.t.

Abū Isḥāq Ibrāhim ibn Mūsa ibn Muḥammad al-Lakhmī asy-Syāṭibī, al-Muwāfaqāt. AsSu'ūdiyyah: Dār Ibn 'Affān, 1997.

Abū Dāwud Sulaimān ibn al-Asy'aṡ as-Sijistānī, Sunan Ab̄̄ Dāwud. Ar-Riyāḍ: Baitu al'Afkār ad-Dauliyyah, t.t.

Abū Bakr 'Abdillāh Muḥammad ibn Ab̄̄ Syaibata al-'Absī al-Kūfì, al-Muṣannafu li Ibni Abī Syaibata, taḥqīq Muḥammad 'Awwāmah. As-Su'ūdiyyah: Dār al-Qiblah li aś-Ṡaq0fah al-islāmiyyah, 2006.

Abū Bakr 'Abd ar-Razzāq ibn Hammām aṣ-Șan'ānī, al-Muṣannaf. Al-Hind: al-Maktabah alIslāmī, 1983.

Abī 'Abdillāh Muḥammad ibn Abī Bakr ibn Ayyūb al-Ma'rūf bi Ibni

Abū Bakr 'Abdillāh Muḥammad ibn Ab̄̄ Syaibata al-'Absī al-Kūfì, al-Muṣannafu li Ibni Abī Syaibata, tahqūq Muḥammad 'Awwāmah. As-Su'ūdiyyah: Dār al-Qiblah li aś-Ṡaqāfah al-islāmiyyah, 2006.

Abī 'Abdillāh Muḥammad ibn Abī Bakr ibn Ayyūb al-Ma'rūf bi Ibni Qayyim al-Jauziyyah, I'lām al-Muwaqqi 'ìn 'an Rabb al-Ālamīn. Al-Mamlakatu al-'Arabiyyah as-Su'ūdiyyah: Dār Ibnu al-Jauzī, $1423 \mathrm{H}$.

Muhammad Tholhah Hasan, Ahlussunnah Wal-Jama'ah: Dalam Persepsi dan Tradisi NU. Jakarta: Lantabora Press, 2014. 